\title{
Russia's electric power reintegration with Central Asia and Caucasus and entering South Asia and Middle East electricity markets
}

\author{
Lev Belyaev ${ }^{1}$, Lyudmila Chudinova ${ }^{1}$, and Sergei Podkovalnikov ${ }^{*}$ \\ ${ }^{1}$ Melentiev Energy Systems Institute of Siberian Branch of the Russian Academy of Sciences, Irkutsk, Russia
}

\begin{abstract}
Results of the next round of studies on Russian interstate electric ties are described. A part of the Eurasian region including European and Siberian part of Russia and countries of Central Asia, Caucasus, Southern Asia and Middle East is considered for 2040 target year. Great effectiveness of creation of interstate power grid in this region is shown.
\end{abstract}

\section{Introduction}

The current political conditions, the desire to synchronize the electric power systems (EPSs) of the Baltic states, Ukraine, Moldova with the EPSs of the EU countries, the restoration of the Central Asian energy connection, the development of the Eurasian Economic Union (EAEU), which has significant energy reserves, and some other circumstances, served as a motivation for additional research of integration electric power projects of Russia in the Caucasian, Central Asian and Middle East directions [1-3 et al.]. The idea of creating a Caspian electric power ring, uniting the power systems of Russia, the countries of Central Asia, the Caucasus, Iran and Turkey, arose. [4]. The target year was assumed to be 2040. These studies are also relevant in the framework of signed in 20192020 documents, such as: Agreement on the joint development of a feasibility study for the project to create the North-South energy corridor between the power systems of the Republic of Azerbaijan, the Islamic Republic of Iran and the Russian Federation [5] and the Protocol on the creation of a common electric power market of five EAEU member states: the Russian Federation, the Republic of Armenia, Belarus, Kazakhstan and Kyrgyzstan [2].

The object of research is a part of the Eurasia region, shown in Fig. 1, where the Interconnected Power Systems (IPSs) of Russia and the countries of Eurasia participating in this interstate power grid (ISPG) are indicated. The countries are shaded with colors corresponding to different nodes of the diagram of the considered ISPG, which will be discussed later. Fig. 1 shows the main interstate electric ties (ISETs) among countries with the direction and the resulting volume of the annual electricity flow (as of 2018). For the cross-sections between the nodes, the large arrows show the number of ISETs of different voltages currently connecting these nodes. The dotted line shows the designed and constructed ISETs.

A distinctive feature of the countries of this region is a significant difference in the provision of energy resources, natural and climatic conditions, economic and political development, and the structure of electricity consumption. Table 1 shows the availability of energy reserves for the countries and subregions of the region.

Table 1. Energy reserves of countries and subregions of Eurasia.

\begin{tabular}{|l|c|c|c|c|c|}
\hline & Russia & $\begin{array}{c}\text { Central } \\
\text { Asia }\end{array}$ & $\begin{array}{c}\text { Afghanistan } \\
\text { \&Pakistan }\end{array}$ & $\begin{array}{c}\text { Turkey } \\
\text { \&Iran }\end{array}$ & $\begin{array}{c}\text { Cauc } \\
\text { asus }\end{array}$ \\
\hline Coal reserves, bln t & 160.4 & 28.3 & 3.1 & 1.6 & 0.4 \\
\hline $\begin{array}{l}\text { Conventional oil } \\
\text { reserves, bln t }\end{array}$ & 14.5 & 4.1 & $<0.1$ & 21.6 & 1.0 \\
\hline $\begin{array}{l}\text { Conventional gas } \\
\text { reserves, trln m3 }\end{array}$ & 35.3 & 21.8 & 0.5 & 33.2 & 1.5 \\
\hline $\begin{array}{l}\text { Uranium resources } \\
\text { (<USD 130/kgU), mln t }\end{array}$ & 214.5 & 472.8 & n. a. & 7.6 & n. a. \\
\hline $\begin{array}{l}\text { Technical potential of } \\
\text { hydropower resources, } \\
\text { TWh/year }\end{array}$ & 1670.0 & 510.0 & 292.0 & 266.0 & 23.0 \\
\hline $\begin{array}{l}\text { Technical potential of } \\
\text { wind energy, TWh/year }\end{array}$ & 21846.0 & 139.2 & 71.0 & 297.0 & 31.0 \\
\hline $\begin{array}{l}\text { Technical potential of } \\
\text { solar energy, TWh/year }\end{array}$ & 76821.0 & $\begin{array}{c}10310 . \\
0\end{array}$ & 4994.0 & 7392.0 & 635.0 \\
\hline
\end{tabular}

The problem statement was set out in 2019 at the International Scientific Workshop "Methodological problems in reliability study of large energy systems" (Tashkent, 23-27.09.2019) [6]. The purpose of the study is to assess the energy and economic efficiency of strengthening and building new interstate electric ties of Russia. Economic efficiency is determined by comparing the values of the annualized costs for the scenarios of the development and functioning of the interconnected EPS with different transfer capacity of ISETs. For this purpose, a special model of optimization of expansion and operation of power

\footnotetext{
* Corresponding author: spodkovalnikov@,isem.irk.ru
} 
national power system (NPS) of Central Asia;

NPS of Caucasus;

NPS of Southern Asia;

[ - INPS of Asia Minor \& Middle East

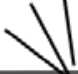

IPS of $\begin{gathered}\text { IPS of } \\ \text { Center }\end{gathered}$

- existing ISETs;

- - - perspective ISETs;

........ non-operating ISETs (tripped. decommissioned. etc.);

$\stackrel{0.138}{\longleftarrow}$ direction of power flows via ISETs (billion $\mathrm{kWh}$ ) (2018)

Fig. 1. A diagram of external electric ties among Russia, Central Asia, Caucasus, Southern Asia and Middle East

systems (ORIRES) developed at Melentiev Energy Systems Institute of Siberian Branch of the Russian Academy of Sciences (ESI SB RAS) was used [3].

The diagram of ISPG is represented by six nodes: 1) the European part of the Russian Federation (including IPSs: of the Center, the Middle Volga, the Urals and the South); 2) node of the IPS of Siberia; 3) Central Asian hub of National Power Systems (NPSs) of Kazakhstan, Uzbekistan, Turkmenistan, Kyrgyzstan, and Tajikistan; 4) Caucasus (NPSs of Armenia, Georgia, Azerbaijan); 5) partially Southern Asia (NPSs of Afghanistan and Pakistan); 6) Asia Minor and Middle East (NPSs of Iran and Turkey) (Fig. 2).

The goal was to determine optimal formation of Eurasian ISPG with effective participation of member countries, including Russia. For this, it was envisaged to build new ISETs of direct current and voltage of \pm 800 $\mathrm{kV}$ with high transfer capacity - according to the most efficient technology, currently mastered in China.

To carry out this work, an assessment of the current and future state of generating equipment, interstate power grid infrastructure was done, programs for the development of the electric power industry of the studied countries were considered, the technical and economic parameters of the facilities under consideration, including power transmissions of $\pm 800 \mathrm{kV}$, were studied. Two scenarios were considered:

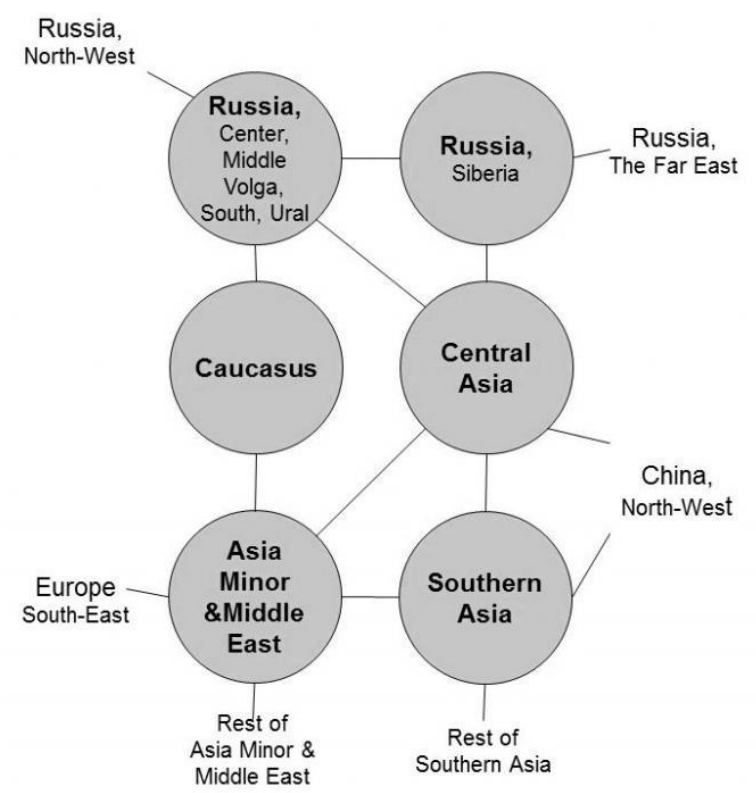

Fig. 2. The diagram of the ISPG

Scenario 1. ISETs parameters correspond to its current state with additional consideration of the transfer capacities of interstate electric ties that are being planned, constructed and will soon be commissioned.

Scenario 2. New interstate transmission infrastructure consisting of $\pm 800 \mathrm{kV} \mathrm{DC}$ transmission 
lines in addition to existed one was assumed to put in place. This substantially rises the transfer capacities of the ISETs allowing countries to exchange intensively electricity and power among each other..

Comparison of the main indicators (capacities additions, investments, objective function value, etc.) of Scenario 2 with the similar total indicators of Scenario 1 allows us to evaluate the optimal development of the transfer capacities of ISETs and the maximum possible system integration effects of NPSs in the ISPG.

\section{Main input data}

Table 2 presents the forecasted combined annual maximums of the electrical load of the IPSs or NPSs included in this node of the ISPG diagram for the considered target year [6].
Table 2. Forecasted annual maxima of electric load, 2040 ,

\begin{tabular}{|c|c|c|c|c|c|}
\hline \multicolumn{6}{|c|}{ GW. } \\
\hline $\begin{array}{c}\text { Russia } \\
\text { (Center, } \\
\text { Middle } \\
\text { Volga, } \\
\text { South, } \\
\text { Ural) }\end{array}$ & $\begin{array}{l}\text { Russia } \\
\text { (Siberia) }\end{array}$ & Caucasus & $\begin{array}{c}\text { Central } \\
\text { Asia }\end{array}$ & $\begin{array}{l}\text { Asia } \\
\text { Minor } \\
\text { and } \\
\text { Middle } \\
\text { East }\end{array}$ & $\begin{array}{c}\text { Southern } \\
\text { Asia }\end{array}$ \\
\hline $\begin{array}{l}140.9 \\
\end{array}$ & 41.8 & 13.3 & 61.3 & 234.3 & 65.0 \\
\hline
\end{tabular}

Table 3 shows the technical and economic parameters of transmission lines, constituting the interstate DC transmission infrastructure of $\pm 800 \mathrm{kV}$ of the considered ISPG [7].

Tables 4 and 5 present main economic indicators of power plants of different types and different fuels [6].

Table 3. Technical and economic indices of interstate electric ties.

\begin{tabular}{|l|c|c|c|}
\hline & Capital investment, USD/kW & $\begin{array}{c}\text { Transmission } \\
\text { losses, \% }\end{array}$ & Route length, km \\
\hline Russia (Siberia) - Central Asia & 377 & 7.8 & 1486 \\
Russia (Center, Middle Volga, South, Ural) - Central Asia & 333 & 6.8 & 131 \\
Russia (Center, Middle Volga, South, Ural) - Caucasus & 267 & 4.7 & 1183 \\
Central Asia - Southern Asia & 202 & 3.4 & 858 \\
Central Asia - Asia Minor and Middle East & 484 & 7.5 & 1867 \\
Southern Asia - Asia Minor and Middle East & 381 & 6.0 & 1502 \\
Caucasus - Asia Minor and Middle East & 272 & 4.3 & 1081 \\
\hline
\end{tabular}

Table 4. Capital investment in new power plants, USD/kW.

\begin{tabular}{|l|c|c|c|c|c|c|}
\hline & Hydro & $\begin{array}{c}\text { Pumped } \\
\text { storage }\end{array}$ & $\begin{array}{c}\text { Thermal, } \\
\text { coal }\end{array}$ & $\begin{array}{c}\text { Thermal, } \\
\text { gas }\end{array}$ & $\begin{array}{c}\text { Thermal, } \\
\text { oil }\end{array}$ & Nuclear \\
\hline Russia & 3000 & 1100 & $\begin{array}{c}1800- \\
2000\end{array}$ & 1200 & & 2800 \\
& & & & & \\
Central Asia & 2100 & 1600 & 2150 & 1250 & & 4300 \\
Southern Asia & 2600 & & 1700 & 1200 & 1400 & 5200 \\
Caucasus & 1500 & & 2000 & 1000 & 1500 & 5500 \\
Asia Minor and & & & & & & \\
Middle East & 2250 & 1000 & 1800 & 670 & 1400 & 4500 \\
\hline
\end{tabular}

Table 5. Fuel costs, USD/kWh.

\begin{tabular}{|l|c|c|c|c|}
\hline & Thermal, coal & Thermal, gas & Thermal, oil & Nuclear \\
\hline Russia & $0.014-0.25$ & $0.027-0.030$ & & 0.004 \\
Central Asia & $0.014-0.017$ & $0.034-0.038$ & 0.099 & 0.004 \\
Southern Asia & 0.034 & 0.041 & 0.100 & 0.006 \\
Caucasus & 0.030 & 0.050 & 0.100 & 0.010 \\
Asia Minor and & & & & \\
Middle East & 0.034 & 0.050 & 0.090 & 0.007 \\
\hline
\end{tabular}

This information has been obtained from various available sources, including the forecast works of national agencies and companies in the region. The indicators of power plants, naturally, reflect differences in natural and climatic conditions and in the cost of fuels. The specific capital investments of power plants were also influenced by the factor of scientific and technological development (progress) of specific countries. This factor had a particularly strong impact on the cost of building nuclear power plants - the most complex technology for generating electricity, mastered in the considered part of Eurasia only in Russia. The rest of the countries are forced to import equipment for nuclear power plants, which leads to an increase in the cost of their construction. This rise in price, apparently, was the reason for the almost double difference in capital investments in nuclear power plants in Russia and other countries.

\section{Results of studies and analysis}

Comparison of the results of optimization calculations for scenarios 1 and 2 shows that enlargement of transfer capacity of the interstate power grid infrastructure (in scenario 2) leads to a decrease in the total costs of the ISPG by $\$ 15.9$ billion per year, including fuel cost by 10.3. At the same time, the total capital investments in power plants and ISETs are reduced by $\$ 29.9$ billion, and the need to commission new power plants by 26.6 GW for the considered target year (Fig. 3, Table 6).

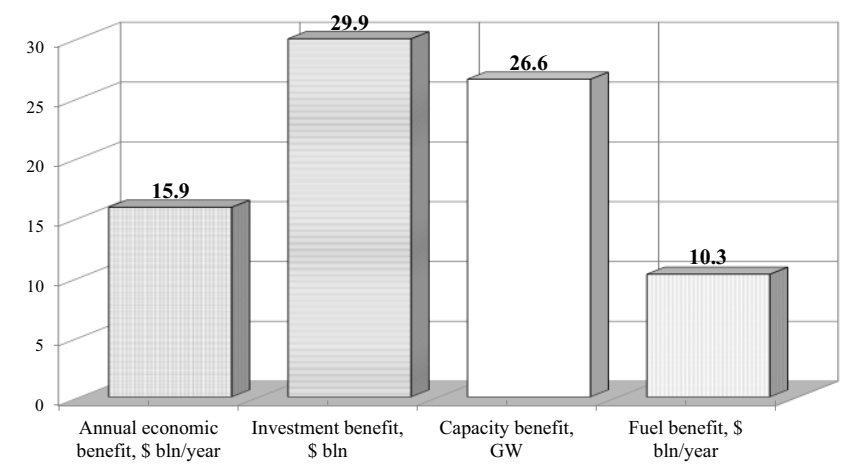

Fig. 3. System benefits of Eurasian Power System Interconnection, 2040 
Table 6. Capital investment, billion US\$.

\begin{tabular}{|c|c|c|c|c|}
\hline & Plants & Lines & Total & $\begin{array}{c}\text { Generating } \\
\text { capacities } \\
\text { additions, GW }\end{array}$ \\
\hline Scenario 1 & 352.593 & 0.121 & 352.714 & 180.3 \\
\hline Scenario 2 & 280.650 & 42.126 & 322.776 & 153.7 \\
\hline \multicolumn{5}{|c|}{ Integration benefits } \\
\hline (1)-(2) & 71.943 & -42.005 & 29.938 & 26.6 \\
\hline
\end{tabular}

To achieve this effect, the construction of about $127 \mathrm{GW}$ of ISETs is required (in Scenario 2 compared to Scenario 1) with capital investments of $\$ 42$ billion; however, reducing the commissioning of power plants saves $\$$ 71.9 billion, i.e. almost 2 times more (Tables 6,7).

Table 7. Optimal transfer capabilities of interstate electric ties, MW.

\begin{tabular}{|c|c|c|c|c|c|c|c|}
\hline Lines & 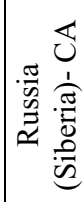 & 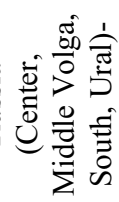 & 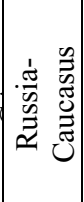 & $\begin{array}{l}\text { 岕 } \\
\text { 崩 }\end{array}$ & ن & 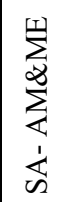 & 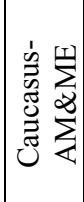 \\
\hline Scenario 1 & 1795 & 5510 & 2580 & 3300 & 900 & 240 & 4230 \\
\hline Scenario 2 & 11200 & 16000 & 29814 & 19385 & 32000 & 4846 & 32000 \\
\hline Changes (2)-(1 & 9405 & 10490 & 27234 & 16085 & 31100 & 4606 & 27770 \\
\hline
\end{tabular}

Figure 4 demonstrates the change in the structure of commissioning of power plants and the distribution of the power effect by country in Scenario 2 in comparison with Scenario 1 . The reduction in capacities occurs in the countries of Asia Minor and Middle East (59.7 GW), Southern Asia (13.9 GW) and the Caucasus (1.5 GW). At the same time, Russia and Central Asia are introducing additional capacities of 23.0 and $25.5 \mathrm{GW}$, respectively. In general, for ISPG, the capacity effect is determined by an increase in the commissioning of gasfired thermal power plants (TPP) and a reduction, to one degree or another, of all other types of power plants. The largest reduction in the commissioning of TPPs on oil (in the Asia Minor and Middle East), which have high fuel costs is $25.6 \mathrm{GW}$.

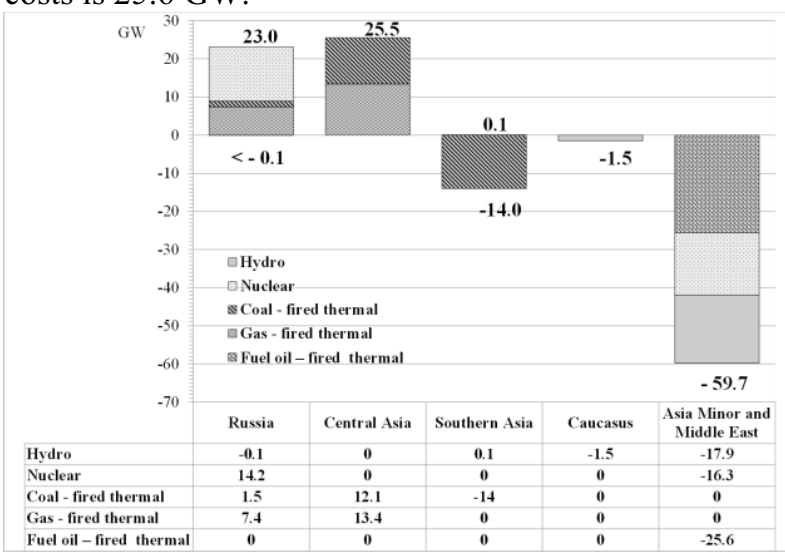

Fig. 4. Change in the structure of power plants, GW

Nuclear power plant (NPP) commissioning is undergoing interesting changes: in the Middle East, they decrease by $16 \mathrm{GW}$, and in Russia, on the contrary, they increase by $14 \mathrm{GW}$. This is explained by the large difference noted above in specific capital investments in NPP in Russia and in the Middle East (in Turkey and Iran). The situation is interesting in that NPP in Turkey and Iran are being built with the participation and support of Russia, and during the construction of the considered ISETs and the creation of the ISPG, these NPP are replaced by new NPPs in Russia itself. In other words, when creating an ISPG in the considered part of Eurasia, competition arises between new NPPs by Russian projects in the Middle East and NPPs in Russia itself. This issue requires a special, more in-depth study.

Changes in the structure of capacities, in turn, lead to a redistribution of electricity production, both by type of generation and by country (Table 8 ). Fuel costs also change accordingly (Table 9).

Table 8. Electricity generation, TWh/year.

\begin{tabular}{|c|c|c|c|c|c|c|c|}
\hline & Hydro\& Pumped storage & Thermal, coal & Thermal, gas & Thermal, oil & Nuclear & Wind \&Solar & Total \\
\hline \multicolumn{8}{|c|}{ Scenario 1} \\
\hline Russia & 190.2 & 256.3 & 947.8 & & 238.9 & 18.3 & 1651.5 \\
\hline Central Asia & 95.8 & 183.2 & 168.9 & 7.9 & 12.8 & 10.8 & 479.4 \\
\hline Southern Asia & 164.4 & 122.3 & 69.9 & 17.2 & 10.1 & 67.7 & 451.6 \\
\hline Caucasus & 24.1 & 0.1 & 66.5 & 4.1 & 4.0 & 2.8 & 101.6 \\
\hline Asia Minor and & & & & & & & \\
\hline Middle East & 130.1 & 421.5 & 614.0 & 217.2 & 212.8 & 191.2 & 1786.8 \\
\hline Total & 604.6 & 983.4 & 1867.1 & 246.4 & 478.6 & 290.8 & 4470.9 \\
\hline \multicolumn{8}{|c|}{ Scenario 2} \\
\hline Russia & 191.0 & 269.3 & 1089.1 & & 376.7 & 18.3 & 1944.4 \\
\hline Central Asia & 96.0 & 287.3 & 325.2 & 8.0 & 12.8 & 10.8 & 740.1 \\
\hline Southern Asia & 165.0 & 6.9 & 95.9 & 13.1 & 10.1 & 67.7 & 358.7 \\
\hline Caucasus & 19.9 & 0.1 & 44.2 & 4.2 & 4.0 & 2.8 & 75.2 \\
\hline Asia Minor and & & & & & & & \\
\hline Middle East & 99.6 & 421.5 & 541.8 & 68.0 & 68.5 & 191.2 & 1390.6 \\
\hline Total & 571.5 & 985.1 & 2096.2 & 93.3 & 472.1 & 290.8 & 4509.0 \\
\hline \multicolumn{8}{|c|}{ Changes in generation of electricity (2) - (1) } \\
\hline Russia & 0.8 & 13.0 & 141.3 & & 137.8 & & 292.9 \\
\hline Central Asia & 0.2 & 104.1 & 156.3 & 0.1 & & & 260.7 \\
\hline Southern Asia & 0.6 & -115.4 & 26.0 & -4.1 & & & -92.9 \\
\hline Caucasus & -4.2 & & -22.3 & 0.1 & & & -26.4 \\
\hline Asia Minor and & & & & & & & \\
\hline Middle East & -30.5 & & -72.2 & -149.2 & -144.3 & & -396.2 \\
\hline Total & -33.1 & 1.7 & 229.1 & -153.1 & -6.5 & & 38.1 \\
\hline
\end{tabular}


Table 9. Fuel costs, US\$ billion / year.

\begin{tabular}{|c|c|c|c|c|c|}
\hline & $\begin{array}{c}\text { Thermal, } \\
\text { coal }\end{array}$ & $\begin{array}{c}\text { Thermal, } \\
\text { gas }\end{array}$ & $\begin{array}{c}\text { Thermal, } \\
\text { oil }\end{array}$ & Nuclear & Total \\
\hline \multicolumn{6}{|c|}{ Scenario 1} \\
\hline Russia & 4.666 & 27.566 & & 0.956 & 33.188 \\
\hline Central Asia & 3.014 & 5.847 & 0.784 & 0.051 & 9.696 \\
\hline Southern Asia & 4.159 & 2.867 & 1.716 & 0.061 & 8.803 \\
\hline Caucasus & 0.003 & 3.323 & 0.408 & 0.040 & 3.774 \\
\hline \multicolumn{6}{|l|}{ Asia Minor and } \\
\hline Middle East & 14.331 & 30.700 & 19.548 & 1.490 & 66.069 \\
\hline Total & 26.173 & 70.303 & 22.456 & 2.598 & 121.530 \\
\hline \multicolumn{6}{|c|}{ Scenario 2} \\
\hline Russia & 4.900 & 31.675 & & 1.507 & 38.082 \\
\hline Central Asia & 4.889 & 11.243 & 0.788 & 0.051 & 16.971 \\
\hline Southern Asia & 0.233 & 3.932 & 1.308 & 0.061 & 5.534 \\
\hline Caucasus & 0.003 & 2.208 & 0.418 & 0.040 & 2.669 \\
\hline \multicolumn{6}{|l|}{ Asia Minor and } \\
\hline Middle East & 14.331 & 27.090 & 6.119 & 0.480 & 48.020 \\
\hline Total & 24.356 & 76.148 & 8.633 & 2.139 & 111.276 \\
\hline \multicolumn{6}{|c|}{ Changes in generation of electricity $(2)-(1)$} \\
\hline Russia & 0.234 & 4.110 & & 0.551 & 4.895 \\
\hline Central Asia & 1.875 & 5.396 & 0.004 & & 7.275 \\
\hline Southern Asia & -3.926 & 1.065 & -0.408 & & -3.269 \\
\hline Caucasus & & -1.115 & 0.010 & & -1.105 \\
\hline Asia Minor and & & & & & \\
\hline Middle East & & -3.611 & -13.430 & -1.010 & -18.051 \\
\hline Total & -1.817 & 5.845 & -13.824 & -0.459 & -10.255 \\
\hline
\end{tabular}

The total electricity production increases in scenario 2 by 38.1 TWh, due to transmission losses in ISETs (Table $3)$. However, fuel costs are reduced by $\$ 10.3$ billion / year due to the improvement of the structure of generation by power plants.

Electricity production is growing strongly in Russia and Central Asia with cheap energy resources, and is decreasing in other nodes of the ISPG diagram, where fuel is much more expensive. In addition, the already noted phenomenon of moving nuclear power plants from the Asia Minor\&Middle East to Russia is emerging. Reducing the capacity and production of electricity from coal, oil and nuclear power plants can provide additional environmental benefit.

As shown above (Table 7), the transmission capacity in all directions of the considered ISETs is increasing significantly, the most development is received by the lines in the directions of Asia Minor \& the Middle East with Central Asia and the Caucasus, $32 \mathrm{GW}$ each, and Russia with Central Asia (up to 27, $2 \mathrm{GW}$ ) and the Caucasus (up to $29.8 \mathrm{GW}$ ). The volumes of transmitted electricity also increase six fold from $320 \mathrm{TWh} /$ year in Scenario 1 to more than $1900 \mathrm{TWh} /$ year in Scenario 2. Moreover, in both scenarios, the main exporters of electricity are Russia - in the directions of the Caucasus and Central Asia; and Central Asia towards Southern and Asia Minor \& the Middle East.

\section{Conclusion}

1. The results obtained confirm the high effectiveness of the development of ISETs in Russia in the CaucasianCentral Asian direction and the formation of the ISPG in this part of Eurasia. In particular, the reintegration of the Unified Power System of Russia and the national power systems of the countries of the Caucasus and Central Asia is highly effective. Moreover, this reintegration is carried out at a new technological level, which ensures intensive exchanges of power and electricity with the corresponding implementation of systemic integration effects that exceed those achieved during the Soviet period. The resulting concentration of the electric power potential of these countries allows them to jointly enter the electric power markets of the countries of Southern and Asia Minor\&Middle East, also receiving economic effects. In addition, the studies carried out made it possible to fill the idea of the Caspian energy ring with concrete content, having preliminarily identified its main parameters, such as the transfer capacities of ISETs, the volumes of electricity and power transmitted through them, and economic indicators. It is advisable to envisage and investigate the relevant projects in bilateral and multilateral negotiations with the countries of the region.

2. The creation of the ISPG is economically beneficial, in fact, to all countries of the Region:

$\square$ for Russia and Central Asian countries in the light of electricity exports;

$\square$ for the countries of the Caucasus, Southern Asia and the Asia Minor\& Middle East when importing electricity.

3. The construction of new Interstate Electric Ties within the framework of the considered ISPG is expedient to focus on power transmission $\pm 800 \mathrm{kV}$. For their design and construction, specialists and companies from the People's Republic of China should be involved, while developing this technology in Russia. There are prerequisites for this in the form of scientific and technical groundwork, made back in the Soviet period.

4. The issue of construction in Russia of exportoriented nuclear power plants for the transmission of electricity to the countries of Southern and Asia Minor and the Middle East, instead of Russia's participation in the construction of nuclear power plants on the territory of these countries, requires a special study. The construction of export nuclear power plants may turn out to be economically efficient and expedient from the point of view of nonproliferation of nuclear weapons, decrease of unemployment and other circumstances.

\section{Acknowledgments}

The research was carried out under State Assignment, Project 17.6.2 (reg. no. AAAA-A17-117030310447-3) of the Fundamental Research of Siberian Branch of the Russian Academy of Sciences and partly supported by the Russian Foundation of Basic Research, Grant No. 18-07-00495.

\section{References}

1. H.A. Shamsiev, Current status and development prospects of the Central Asian Unified Energy System (Energiya Coordinating Dispatch Center, Tashkent, 2019) [Electronic resource]. Access mode: https://www.carecprogram.org/uploads/4.-DispatchCenter_Mr-Shamsiev.pdf 
2. The presidents of the five member states of the EAEU of the Russian Federation, the Republic of Armenia, Belarus, Kazakhstan and Kyrgyzstan signed a protocol on the creation of a common electricity market (Ministry of Energy of the Russian Federation, 29.05.2020) [Electronic resource]. Access mode: minenergo.gov.ru/node/14908. (in Russian)

3. L.S. Belyaev, S.V. Podkovalnikon, V.A. Saveliev, L.Yu. Chudinova, Effectiveness of interstate electric ties (Novosibirsk, Science, 2008) (in Russian)

4. O.M. Budargin, Electric power industry - a driver of global power unions. Electric power. Transmission and distribution, 3, (2017) (in Russian)

5. Russia, Azerbaijan and Iran signed an agreement on the joint development of a feasibility study for a project to connect the energy systems of the three countries (System Operator of the UES, 14.08.2019). [Electronic resource]. Access mode: http://www.soups.ru/index.php?id=press_release_view\&tx_ttnews[ tt_news] $=14758 \& \mathrm{cHash}=\mathrm{a} 5 \mathrm{f} 3 \mathrm{e} 97 \mathrm{f} 2 \mathrm{~d}$. (in Russian)

6. S.V. Podkoval'nikov, L.Yu. Chudinova, Strategic cooperation of electric power systems of Russia and Central Asia for the creation of common Eurasian electric power space. E3S Web Conf., 139 (2019). [Electronic resource]. Access mode: https://doi.org/10.1051/e3sconf/201913901003

7. Global electricity network. Feasibility study. (CIGRE, 2019) [Electronic resource]. Access mode: https://orbi.uliege.be/bitstream/2268/239969 /1/CIGRE-GLOBAL_GRID-REPORT.pdf 